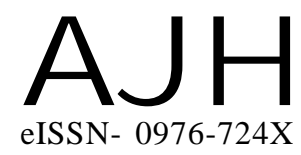

Article history :

Received : 04.09.2015

Revised : 03.05.2016

Accepted : 12.05.2016

Members of the Research Forum

Associated Authors:

${ }^{1}$ Department of Horticulture, College of Agriculture, Junagadh

Agricultural University, JUNAGADH (GUJARAT) INDIA
Author for correspondence : SANDEEP SINGH

Department of Horticulture, College of Agriculture, Junagadh

Agricultural University, JUNAGADH (GUJARAT) INDIA

Email : brarsingh88@gmail.com
THEASIAN JOURNALOF HORTICULTURE

Volume 11 | Issue 1 | June, 2016 | 168-171

Visit us -www.researchjournal.co.in

\title{
To study the effect of pinching on yield and quality of carnation varieties grown under protected condition
}

\section{SANDEEP SINGH, K.M. KARETHA ${ }^{1}$, VIRENDRA SINGH ${ }^{1}$ AND ANKIT CHOURASIA ${ }^{1}$}

ABSTRACT : An experiment was conducted to study the effect of pinching methods on carnation under protected condition. The results of present investigation revealed that the variety Liberty $\left(\mathrm{V}_{2}\right)$ recorded significantly the highest number of flowers per plant (6.23), number of flowers per square meter (205.70) and flower yield per hectare (2077778 Numbers). As per quality point of view the variety Farida $\left(\mathrm{V}_{3}\right)$ recorded significantly the highest vase life (12.33 days) and longevity of flowers (16.98 days). The treatment $\mathrm{P}_{3}$ (Double pinch) resulted in significantly the highest number of flowers per plant (6.75), number of flowers per square meter (222.75) and flower yield per hectare (2250000 Numbers). The treatment $\mathrm{P}_{1}$ (Single pinch) recorded significantly the highest vase life (11.94 days) and longevity of flowers (15.61 days).

KEY WORDS : Pinching, Yield, Vase life, Carnation

HOW TO CITE THIS ARTICLE : Singh, Sandeep, Karetha, K.M., Singh, Virendra and Chourasia, Ankit (2016). To study the effect of pinching on yield and quality of carnation varieties grown under protected condition. Asian J. Hort., 11(1) : 168-171, DOI : 10.15740/HAS/TAJH/11.1/168-171. 